\title{
Rhinovirus, Coronavirus, Enterovirus, and Bocavirus After Hematopoietic Cell Transplantation or Solid Organ Transplantation
}

\author{
Alpana Waghmare and Michael Boeckh
}

\section{$32.1 \quad$ Rhinoviruses}

\subsubsection{Epidemiology}

Human rhinoviruses (HRVs), the viruses predominantly associated with the common cold, are highly prevalent in both immunocompetent and immunocompromised individuals. Prior to the development of sensitive molecular viral detection assays, influenza, respiratory syncytial virus, and parainfluenza virus were the most common and most concerning respiratory viral pathogens detected in hematopoietic cell transplant (HCT) recipients [1]. Due to the development of polymerase chain reaction (PCR) assays for viral detection, HRVs are now known to be the most common viruses detected from respiratory specimens in HCT recipients and can account for $25-40 \%$ of cases of viral respiratory infections in these patients [2-4] (Figure 32-1). Due to their high prevalence and their ability to cause progressive infection, HRVs are also a significant cause of lower respiratory tract infection (LRTI) in HCT recipients (Table 32-1). HRV infection is also common in solid organ transplant (SOT) recipients, although the incidence is not known among SOT recipients as a whole. In lung transplant recipients, data from older retrospective and prospective studies suggests an incidence of 35-55\% among patients with positive respiratory samples [5-7] (Figure 32-2). In a recent prospective surveillance study of 112 lung transplant recipients, HRVs represented $62 \%$ of all positive samples [8]. Among symptomatic lung transplant recipients, HRV represented $34 \%$ of all respiratory viruses detected [9].

HRVs are members of the Picornaviridae family and are classified into three species, HRV-A, HRV-B, and HRV-C, based on similarity in genome organization, capsid features, and conserved sequences [10]. The total number of genotypes continues to grow as new genotypes are characterized; currently at least 160 unique genotypes are described. Due to poor growth in traditional viral culture models, HRV-C was only recognized after the development of molecular diagnostic techniques. Thus, HRV-C is not a novel species, but rather one that has been circulating unnoticed due to lack of an appropriate diagnostic assay. There are several biologic characteristics of HRV-C that differentiate the species from HRV-A and HRV-B. HRV-A and HRV-B both use ICAM-1 or LDLR for cell attachment and entry, whereas it appears that HRV-C may utilize a distinct receptor, cadherin-related family member 3 , that is associated with asthma susceptibility [11, 12]. Additionally, HRV-C species are stable at higher temperatures and readily infect upper and lower airways, whereas HRV-A and HRV-B species tend to be more limited to the sinuses and upper airways $[13,14]$. These biologic characteristics are thought to play a role in variations in clinical outcomes observed among the different species.

\subsubsection{Clinical Characteristics}

Most immunocompetent patients with HRV present with an afebrile, self-limited syndrome characterized by rhinorrhea, nasal congestion, and malaise, and less frequently sore throat, mild cough, and hoarseness [15-19]. HRV may also be associated with exacerbations of sinusitis, chronic bronchitis, and asthma, and with lower respiratory tract syndromes and atypical pneumonias in otherwise healthy people, including the young and the elderly [20,21]. The specific mechanisms by which HRVs produce lung diseases are not well understood. HRVs are also implicated in asthma and chronic obstructive pulmonary disease (COPD) exacerbations, but again the mechanisms are poorly defined.

With the widespread availability of PCR diagnostics, data are emerging on the incidence and clinical relevance of HRV infections in immunocompromised patients. Early studies relied on culture to detect HRV, a specific but insensitive method because the standard viral culture systems are not optimized for HRV detection, especially HRV-C [22]. For example, a Fred Hutchinson Cancer Center surveillance study from 1987 to 1992 detected HRVs in 29 specimens, and only one was from a lower respiratory tract specimen [2]. A prospective 5-year study at MD Anderson Cancer 
FIgURE 32-1. Cumulative incidence of first infection episodes of HRV, $\mathrm{HCoV}$, and other respiratory viruses (RSV, PIV, HMPV, influenza, adenovirus) after transplantation in 215 HCT recipients. Reproduced from Blood, Human rhinovirus and coronavirus detection among allogeneic hematopoietic stem cell transplantation recipients, Filippo Milano, Angela P. Campbell, Katherine A. Guthrie, Jane Kuypers, Janet A. Englund, et al., 115 (10): 2088-2094, 2010, with permission from Springer Science and Business Media.

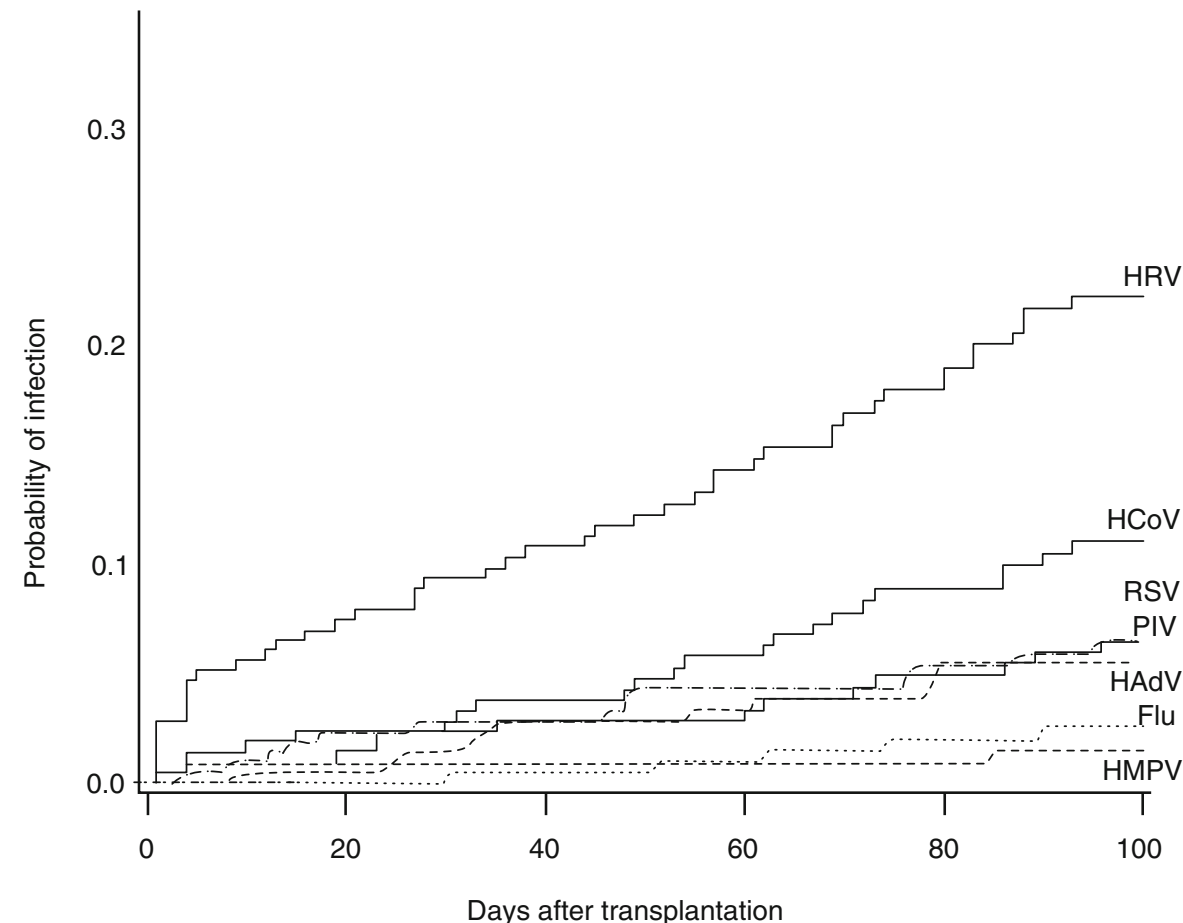

Days after transplantation

TABLE 32-1. Summary of clinical manifestations of rhinoviruses, coronaviruses, enteroviruses, and bocavirus

\begin{tabular}{|c|c|c|c|c|c|}
\hline Virus & $\begin{array}{l}\text { Upper respiratory } \\
\text { tract infection }\end{array}$ & $\begin{array}{l}\text { Lower respiratory } \\
\text { tract infection }\end{array}$ & Other manifestations & Treatment & Comments \\
\hline $\begin{array}{l}\text { Human } \\
\text { rhinovirus }\end{array}$ & ++++ & ++ & & Supportive care & $\begin{array}{l}\text { May be associated with severe } \\
\text { disease in immunocompromised } \\
\text { hosts }\end{array}$ \\
\hline Coronavirus & +++ & + & $\begin{array}{l}\text { Gastrointestinal disease in } \\
\text { children }\end{array}$ & Supportive care & $\begin{array}{l}\text { Recent outbreaks of severe acute } \\
\text { respiratory syndrome (SARS) } \\
\text { and middle east respiratory } \\
\text { syndrome (MERS) }\end{array}$ \\
\hline Enterovirus & ++ & + & $\begin{array}{l}\text { Neurologic disease } \\
\text { (poliomyelitis, meningitis, } \\
\text { encephalitis), cardiac disease, } \\
\text { muscle disease, eye infections }\end{array}$ & Supportive care & $\begin{array}{l}\text { Sporadic outbreaks described, } \\
\text { including Enterovirus-D68 }\end{array}$ \\
\hline Bocavirus & ++ & $?$ & & Supportive care & \\
\hline
\end{tabular}

Center cultured specimens specifically for HRVs at lower temperatures with roller culture methods, and reported that HRV infections were associated with substantial morbidity and mortality in 7 of $22(32 \%)$ myelosuppressed patients [23]. In that study, approximately one third of the adult HCT recipients who developed symptomatic HRV infections prior to engraftment had progression of upper respiratory tract symptoms to LRTI, and all cases with pneumonias were fatal. Lung biopsies and autopsies revealed findings consistent with interstitial pneumonitis and/or ARDS, but no in situ evaluation was performed to definitively assess HRV infection. Similar reports with evidence of LRTI based on radiographic and BAL findings continue to be noted [24-26], but it remains unknown if pneumonia is a direct cause of viral invasion of the lung tissue or by host responses in the lung. Evidence for in vitro and in vivo replication in lower respiratory tract has been shown in experimental infection, where HRV was isolated from human volunteers after intranasal HRV challenge by in situ hybridization [27]. The use of RT-PCR continues to provide new information about the frequency of HRV infection. In a study of BAL samples from 77 HCT recipients that were tested using RT-PCR, HRV was detected in six patients $(8 \%)$, mortality rate was very high $(83 \%)$ and two of the six patients showed persistent HRV infection. However, all of the HRV-infected patients had significant coinfections and it was not certain whether HRV 

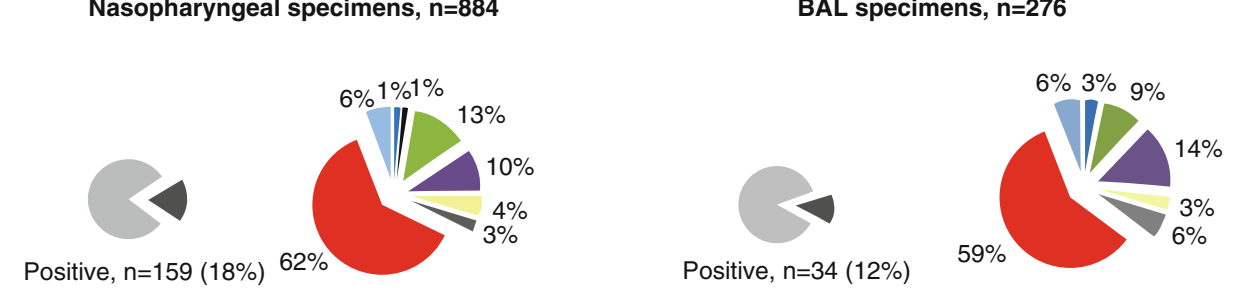

b Emergency visits ( $\mathrm{n}=\mathbf{2 0 9})$

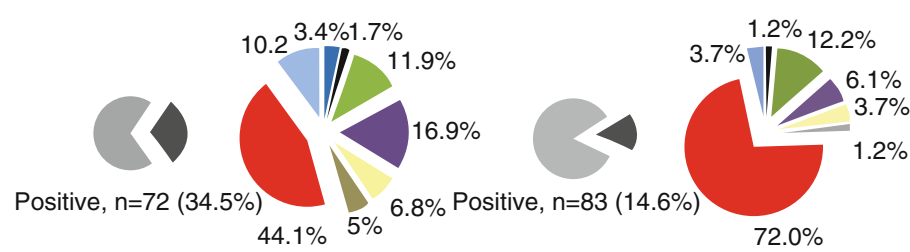

Overall proportion of $\square$ positive or negative (RT)-PCR

Adenovirus Bocavirus Coronavirus $\square$ Influenza Metapneumovirus $\square$ Parainfluenza $\square$ Picornavirus RSV
Regular visits $(n=124)$

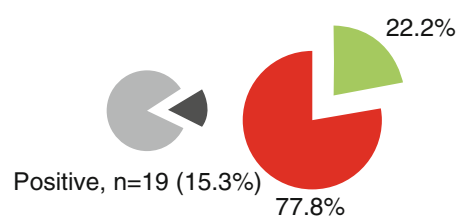

FIGURE 32-2. Distribution of viruses in lung transplant recipients. (a) Viruses recovered in upper and lower respiratory specimens. (b) Viruses recovered according to visit type. Reproduced from Thorax, Pierre Olivier Bridevaux, J.D. Aubert, P. M. Soccal, J. MazzaStalder, C. Berutto, Incidence and outcomes of respiratory viral infections in lung transplant recipients: A prospective study, 69, pages 32-38, copyright 2014, with permission from BMJ Publishing Group Ltd.

infection was the direct cause of poor prognosis [25]. In a small cohort of patients with hematologic malignancy, LRTI was associated with hypoalbuminemia and bacterial copathogens were seen in 25\% of patients [28].

Recent studies have shown that immunocompromised adults with HRV demonstrated similar hospital admission rates, intensive care unit admissions, and mortality rates as patients with pandemic H1N1 influenza [29]. Several reports have linked HRV infection to severe respiratory failure and even death [23-25]. Furthermore, recently presented data suggest that LRTI associated with HRV leads to a mortality rate comparable to that of RSV, influenza virus, and PIV [30], independent of the presence of co-pathogens. Risk factors for mortality following HRV LRTI included bone marrow stem cell source, oxygen requirement at time of diagnosis, and steroid use $\geq 1 \mathrm{mg} / \mathrm{kg}$ prior to diagnosis [30]. Other factors that may influence clinical severity include the presence of HRV RNA in blood, viral load, and HRV species type; however, no data exist in immunocompromised patients to date. HRV viral RNA was detected in the sera of $30(12 \%)$ of 243 pediatric patients with severe HRV respiratory infection, with HRV-C being the predominant species [31]. In healthy pediatric patients, increased respiratory viral load has been associated with HRV LRTI and HRVC has been implicated as a more virulent pathogen [32-34]. Others, however, have shown lack of correlation between HRV-C and oxygen requirement, length of hospitalizations, and coinfections [35]. The predominance of HRV-C in HCT recipients has also been described in small studies, with higher rates of pneumonia in patients with HRV-C detected from the upper respiratory tract [36]. In a small cohort of patients with hematologic malignancies, the rate of LRTI was not different between patients infected with HRV-A, HRV-B, or HRV-C [28]. The relative risk of HRV-C infection in the immunocompromised population remains unknown, and more research is needed to define the role of strain differences on outcomes.

Detection and diagnosis of respiratory viral infections prior to transplant is a common clinical concern that has until recently only been evaluated in small cohorts for certain viruses [37-40]. In a large, prospective surveillance cohort of allogeneic HCT recipients, detection of HRV pretransplant was associated with significantly fewer days alive and out of the hospital, and significantly higher mortality at 100 days posttransplant [41]. Further, larger prospective studies are needed to determine risk factors for posttransplant complications, the role of viral load and symptom burden at the time of transplantation, and the need to potentially delay transplantation for patients with HRV present prior to transplantation. Ultimately, the issue of viral causality of disease and evaluation of prophylactic and treatment modalities will need to be addressed. The impact of HRV infection prior to SOT is not known.

Like HCT recipients, SOT recipients are exposed to highly immunosuppressive regimens that leave them susceptible to respiratory viral infections. Lung transplant recipients have the added disadvantage of altered lung immunity due to factors such as impaired ciliary clearance, poor cough reflex, and abnormal lymphatic drainage. These factors can predispose to lower respiratory tract infections. The impact of HRV on outcomes in lung transplant recipients can range from 
asymptomatic infection to severe disease. In a pooled analysis of all respiratory viruses detected in lung transplant recipients, viruses were detected five times more frequently when respiratory symptoms were present [42]. A correlation between higher symptom scores and higher rhinovirus load in the upper respiratory tract has been demonstrated, although even asymptomatic patients can have relatively high viral loads [43]. The relative rate of progression from upper to lower tract disease for HRV specifically is not known, although the effect on lung function has been evaluated in aggregate for all respiratory viruses and suggests a decline in forced expiratory volume (FEV1) of $-5 \%$ to $-30 \%$ [42]. For HRV specifically, the FEV1 loss was similar to that seen in other respiratory viruses [8]. The correlation between respiratory viral infections and acute rejection, chronic rejection, and bronchiolitis obliterans syndrome (BOS) remains somewhat unclear, with several conflicting findings when respiratory viruses were evaluated in aggregate [6-8]. A recent large cohort of 250 lung transplant recipients, however, showed an independent association between respiratory viral infections (34\% HRV) and chronic lung allograft dysfunction in multivariate models [9]. This association was influenced by time, with more of an effect within a shorter period following respiratory infection. Larger, prospective studies investing individual viruses are needed to clearly assess the impact on these outcomes.

\subsubsection{Diagnosis}

Unlike paramyxoviruses, HRV infection cannot be diagnosed based on characteristic histopathologic changes or changes in cell morphology. In the past, cell culture was used to diagnose $\mathrm{HRV}$ infection using multiple cell lines at low temperatures of $33-34{ }^{\circ} \mathrm{C}$, often in rolling tubes. The cell lines utilized for the detection of HRVs may detect enteroviruses; HRV isolates are distinguished from enteroviruses by their lability in acid (loss in viral titer following exposure to a $\mathrm{pH}$ of 5). There are no commercially available antigen-detection assays or simple kits for the detection of HRV.

RT-PCR has dramatically improved the ability to both detect and characterize HRVs, with current assays at least two to three times more sensitive than conventional culture methods [44]. Some PCR assays are able to distinguish between enteroviruses and HRVs instead of the acid lability assays [45]. Typing of HRVs based on PCR amplification sequence variations in $5^{\prime}$-noncoding region also has been described [46]. New standardized methods to detect more of the over 100 strains of HRV have now been described [47]; however, commercially available multiplex respiratory viral PCR panels contain primer/probe sets that can cross-react between enterovirus and HRV strains. New strains and types of HRV are being detected frequently and more diseases associated with HRV are being described using new and diverse molecular methods.

\subsubsection{Treatment Options}

There are no approved antivirals for the treatment of HRV infections. Several agents have been evaluated in preclinical and clinical trials for the treatment of HRV infection in immunocompetent hosts, including capsid binding inhibitors, protease inhibitors, and RNA synthesis inhibitors [48]. None of these agents have been evaluated in immunocompromised hosts. Given the high prevalence and potential severity of HRV infection in this population, there is a great need for drug development and clinical trials for the prevention and treatment of LRTI. Outside of transplant recipients, there is a potential need for intervention in other populations such as patients with asthma or COPD to prevent disease exacerbation $[49,50]$.

\subsection{Coronaviruses}

\subsubsection{Epidemiology}

CoVs are a frequent cause of the common cold, but little is known about the role of CoVs in immunocompromised patients [51] (Table 32-1). Human group 1 (subtypes 229E and NL63) and human group 2 (OC43 and HKU1) CoVs were originally reported as causes of human respiratory illnesses. The availability of more sophisticated diagnostic tools, such as RT-PCR, has facilitated the detection of CoVs in normal and immunocompromised persons. These improved molecular methods of viral discovery facilitated the recent identification of the novel Group 1 and 2 human CoV subtypes - NL63 in 2004 [52] and HKU1 in 2005 [53]. A more accurate clinical epidemiology of $\mathrm{CoV}$ infection is beginning to emerge. It is now known that all four known subtypes of CoV circulate simultaneously [54], and that in addition to the common cold, $\mathrm{CoV}$ is associated with upper respiratory tract infection and LRTI in persons with and without underlying conditions $[55,56]$. In lung transplant recipients, CoVs appear to be the second most common respiratory viruses after picornaviruses with a detection rate of $13-27 \%$ of positive samples [5-7] (Figure 32-2). In a prospective surveillance cohort of lung transplant recipients, coronaviruses were detected in $13 \%$ of all positive samples, again only second to picornaviruses [8].

Two additional CoVs associated with outbreaks are the severe acute respiratory syndrome-associated CoV (SARS$\mathrm{CoV}$ ) and the recently described Middle East respiratory syndrome-CoV (MERS-CoV). The SARS outbreak originated in Guangdong Province in China in 2002 and was characterized by a life-threatening, atypical pneumonia and was spread by close contact with infected humans, mostly to household contacts and health care workers [57]. SARS$\mathrm{CoV}$ is not currently circulating in the world with the most recent human cases of infection reported in China in 2004 [58]. MERS-CoV first emerged in the Arabian Peninsula in 2012, and since then travel-associated cases have been found 
in a number of countries outside the region [59]. In adults, the fatality rate is estimated to be $40 \%$; in children asymptomatic infection is common but patients with underlying medical conditions are at increased risk [60,61]. There is little data on the incidence of SARS-CoV and MERS-CoV in immunocompromised hosts, although immune suppression is considered a risk factor. SARS-CoV has been described in liver transplant recipients and in patients with myelodysplastic syndrome [62, 63]. MERS-CoV has been described in patients on chronic immunosuppression and in renal transplant recipients with a broad range of clinical presentations $[64,65]$. Other CoVs have been reported to cause pneumonia in children and immunocompromised patients treated for hematologic malignancies [66-68]. The role of coronavirus virus infection prior to transplantation is not known.

\subsubsection{Clinical Characteristics}

Although most $\mathrm{CoV}$ infections result in relatively mild upper respiratory tract infection, these viruses have been associated with more severe LRTI (e.g., bronchiolitis and pneumonia) in patients who are immunosuppressed, have asthma, or are premature. In one retrospective study carried out over 1 year, $\mathrm{CoV}$ was detected in six immunocompromised children-five with acute lymphocytic leukemia and one renal transplant recipient [54]. Five patients were febrile at the time coronavirus was present, with fevers lasting 1-7 days. All patients initially presented with rhinorrhea and nasal discharge; two children had cough as a presenting symptom. Chest radiographs of only one of the three children were abnormal; LRTI based on decreased oxygen saturation, tachypnea, and abnormal chest radiograph was present in only one child with leukemia, who was significantly neutropenic and lymphopenic at the time $\mathrm{CoV}$ was detected. CoVs have been associated with LRTI in HCT recipients with sometimes fatal outcomes [66, 67, 69-71]. The clinical characteristics of SARS-CoV and MERS-CoV infection in HCT and SOT patients are not well described, and presentation can range from mild symptoms to respiratory failure and death [62-65, 72].

\subsubsection{Diagnosis}

Until the advent of RT-PCR, techniques for the detection of $\mathrm{CoV}$ were limited and the reliable identification of $\mathrm{CoV}$ was problematic. Early detection techniques isolated two subtypes-OC43 and 229E, originally using organ cultures of human embryonic trachea, with morphology determined using negative staining with electron microscopy [73]. With the advent of molecular detection methods and increased interest in $\mathrm{CoV}$ detection during the SARS outbreak, new strains of CoVs have been discovered and new RT-PCR assays developed that facilitate further studies of these viruses. Based on RT-PCR assays, four strains of non-SARS CoVs (OC43, 229E, NL63, and HKU1) appear to cocirculate during the non-summer months in temperate climates, and are associated with symptomatic disease in immunocompromised hosts [54]. Guidance on RT-PCR and serologic assays for the confirmation on MERS-CoV can be found on the World Health Organization website [74].

\subsubsection{Treatment Options}

There are no approved antivirals for prophylaxis or treatment of $\mathrm{CoV}$ infections and supportive care remains paramount in managing patients infected with coronaviruses. Though several antivirals were used during the SARS-CoV epidemic, no clear benefit could be established on systematic review [75]. Oral ribavirin was evaluated in retrospective studies for the treatment of MERS-CoV in immunocompetent individuals; decreased survival was noted in one study when compared to matched controls [76, 77], however, larger prospective studies are needed to show true efficacy. Shedding of all coronaviruses may persist for up to months, and routine infection control practices are encouraged.

\subsection{Enteroviruses}

\subsubsection{Epidemiology}

EVs are part of the picornaviridae family of viruses and can be associated with severe illness in immunocompromised hosts. EVs include polioviruses, coxsackieviruses, and echoviruses; these are now all classified into four species: Enterovirus A (EV-A), EV-B, EV-C, and EV-D. Risk for infection and subsequent poor outcomes appears to be heavily influenced by age, although factors such as sex and socioeconomic status play a role in the general population. EV activity can be either sporadic or epidemic, and several outbreaks have been described. EVs are typically found during the summer and early autumn in temperate climates.

Enterovirus-D68 (EV-D68) was first identified in California in 1962 [78] and has since been associated with several small outbreaks, both in the US and internationally, from 2009 to 2013 [79-84]. In the summer of 2014, several hundred cases of severe respiratory illnesses in children in the United States were found to be associated with EV-D68 infection [85], and several additional clusters have been described worldwide [86-96].

\subsubsection{Clinical Characteristics}

EVs can cause a wide spectrum of illnesses in immunocompetent individuals including asymptomatic infection, poliomyelitis, meningitis, encephalitis, cardiac disease, muscle disease, eye infections, respiratory infections, exanthems, and neonatal disease. The most frequently described manifestation 
in immunocompromised patients is respiratory disease, although the incidence and spectrum of disease is not known. According to one study, EVs can be associated with lower respiratory tract infection and mortality; however, larger studies are needed to establish specific risk factors for worse outcomes [97].

Most confirmed cases of EV-D68 infection have been in children, occurring primarily in patients with underlying lung disease such as asthma or a history of wheezing. EV-D68 was also associated with several cases of acute flaccid paralysis in children during the 2014 outbreak in the United States, although definitive causation has not yet been established [98, 99]. The impact of EV-D68 infection in immunocompromised hosts is not known; however, the association between EV-D68 and severe illness was described in eight adult immunocompromised patients with presumptive EV-D68 infection including HCT recipients [100]. Additionally, one recent report of adults with confirmed EV-D68 infection included solid organ transplant recipients [87].

\subsubsection{Diagnosis}

Depending on the clinical scenario, EVs can be detected from a number of clinical specimens including cerebral spinal fluid, serum, respiratory specimens, cardiac tissue, and stool. EVs may be identified in throat samples as well as fecal specimens and cerebrospinal fluid. Commercial multiplex PCR assays contain primer/probe sets that may cross react between rhinoviruses and enteroviruses. A specific EVD68 RT-PCR has been developed by the CDC and has been made publically available [101].

\subsubsection{Treatment Options}

There are no approved antivirals approved for the treatment of EVs. Intravenous immunoglobulin (IVIG) has been used in the treatment of neonatal enteroviral sepsis, but the effect on clinical outcomes is highly dependent on the presence of specific neutralizing antibodies and timing of administration [102, 103]. Pleconaril, an oral capsid inhibitor with activity against picornaviruses, has been evaluated in treatment of enteroviral infections including meningitis, neonatal sepsis, and respiratory infections [104-108] but is not available for treatment. Other capsid binders, protease inhibitors, and polymerase inhibitors are in various stages of development, but none are currently available for treatment of enteroviral infections [109]. No studies have shown efficacy in immunocompromised hosts.

\subsection{Bocavirus}

Human bocavirus $(\mathrm{HBoV})$ is a newly identified human parvovirus that was originally identified by random PCR amplification/cloning technique on pooled respiratory secretions from hospitalized children with respiratory tract symptoms [110]. This virus was named "human bocavirus," due to its relatedness to the genome organization of two other parvoviruses, bovine parvovirus and minute virus of canines, in the family Parvoviridae. This virus continues to be detected in young children with a winter seasonality [111-113]. The relationship of $\mathrm{HBoV}$ and respiratory disease in immunocompromised patients is not yet clear. Preliminary evidence to date demonstrates case reports of disseminated $\mathrm{HBoV}$ infection with involvement of the respiratory tract, blood, and stool in several patients, sometimes associated with GVHD and prolonged viral shedding in the feces $[114,115]$. Other studies have reported little evidence linking this virus with pulmonary pathology or severe respiratory disease in HCT or lung transplant recipients [116-118]. Further research is necessary to link this virus with the disease in the transplant recipient. No specific antiviral therapy is available.

\subsection{Future Directions and Unmet Needs}

Respiratory viruses are a significant concern following HCT and SOT and can be associated with substantial morbidity and mortality, even among viruses traditionally not concerned pathogenic. New, sensitive diagnostic assays allow for routine detection of rhinoviruses, enteroviruses, coronaviruses, and bocavirus, and additional data on the epidemiology, risk factors, outcomes of infection, and the impact of different viral strains are desperately needed. Preliminary studies suggest that detection of these viruses prior to transplant may affect outcomes, but additional studies are needed to explore this important clinical area. Furthermore, as new antivirals are being developed, it will be important to identify high-risk patients that may benefit from treatment. Finally, a better understanding of these viruses will be able to inform better infection prevention strategies that will remain the mainstay of viral control.

\section{References}

1. Ljungman P, Ward KN, Crooks BNA, Parker A, Martino R, Shaw PJ, et al. Respiratory virus infections after stem cell transplantation: a prospective study from the Infectious Diseases Working Party of the European Group for Blood and Marrow Transplantation. Bone Marrow Transplant. 2001; 28(5):479-84.

2. Bowden MDRA. Respiratory virus infections after marrow transplant: the Fred Hutchinson cancer research center experience. Am J Med. 1997;102(3):27-30.

3. Hassan IA, Chopra R, Swindell R, Mutton KJ. Respiratory viral infections after bone marrow/peripheral stem-cell transplantation: the Christie hospital experience. Bone Marrow Transplant. 2003;32(1):73-7.

4. Milano F, Campbell AP, Guthrie KA, Kuypers J, Englund JA, Corey L, et al. Human rhinovirus and coronavirus detection among allogeneic hematopoietic stem cell transplantation recipients. Blood. 2010;115(10):2088-94. 
5. Kumar D, Erdman D, Keshavjee S, Peret T, Tellier R, Hadjiliadis D, et al. Clinical impact of community-acquired respiratory viruses on bronchiolitis obliterans after lung transplant. Am J Transplant. 2005;5(8):2031-6.

6. Soccal PM, Aubert JD, Bridevaux PO, Garbino J, Thomas Y, Rochat $\mathrm{T}$, et al. Upper and lower respiratory tract viral infections and acute graft rejection in lung transplant recipients. Clin Infect Dis. 2010;51(2):163-70.

7. Kumar D, Husain S, Chen MH, Moussa G, Himsworth D, Manuel $\mathrm{O}$, et al. A prospective molecular surveillance study evaluating the clinical impact of community-acquired respiratory viruses in lung transplant recipients. Transplantation. 2010;89(8):1028-33.

8. Bridevaux PO, Aubert JD, Soccal PM, Mazza-Stalder J, Berutto C, Rochat T, et al. Incidence and outcomes of respiratory viral infections in lung transplant recipients: a prospective study. Thorax. 2014;69(1):32-8.

9. Fisher CE, Preiksaitis CM, Lease ED, Edelman J, Kirby KA, Leisenring WM, Boeckh M, Limaye AP. Symptomatic respiratory virus infection and chronic lung allograft dysfunction. Clin Infect Dis. 2016;62(3):313-9.

10. Palmenberg AC, Rathe JA, Liggett SB. Analysis of the complete genome sequences of human rhinovirus. J Allergy Clin Immunol. 2010;125(6):1190-9. quiz 200-1.

11. Vlasak M, Roivainen M, Reithmayer M, Goesler I, Laine P, Snyers L, et al. The minor receptor group of human rhinovirus (HRV) includes HRV23 and HRV25, but the presence of a lysine in the VP1 HI loop is not sufficient for receptor binding. J Virol. 2005;79(12):7389-95.

12. Bochkov YA, Watters K, Ashraf S, Griggs TF, Devries MK, Jackson DJ, et al. Cadherin-related family member 3, a childhood asthma susceptibility gene product, mediates rhinovirus $\mathrm{C}$ binding and replication. Proc Natl Acad Sci U S A. 2015;112(17):5485-90.

13. Bochkov YA, Gern JE. Clinical and molecular features of human rhinovirus C. Microbes Infect. 2012;14(6):485-94.

14. Ashraf S, Brockman-Schneider R, Bochkov YA, Pasic TR, Gern JE. Biological characteristics and propagation of human rhinovirus- $\mathrm{C}$ in differentiated sinus epithelial cells. Virology. 2013;436(1):143-9.

15. Arruda E, Pitkaranta A, Witek Jr TJ, Doyle CA, Hayden FG. Frequency and natural history of rhinovirus infections in adults during autumn. J Clin Microbiol. 1997;35(11):2864-8.

16. Johnston SL. Natural and experimental rhinovirus infections of the lower respiratory tract. Am J Respir Crit Care Med. 1995;152(4 pt 2):S46-52.

17. Gern JE, Palmenberg AC. Rhinoviruses. In: Knipe DM, Howley PM, editors. Fields virology. 6th ed. Philadelphia: Lippincott Williams \& Wilkins; 2013. p. 531-49.

18. Couch MDRB, Englund MDJA. Respiratory viral infections in immunocompetent and immunocompromised persons. Am J Med. 1997;102(3):2-9.

19. Gwaltney J, Rueckert R. Rhinovirus. In: Richman DD, Whitley RJ, Hayden FG, editors. Clinical virology. New York: Churchill Livingstone; 1997. p. 1025-47.

20. Gern JE, Galagan DM, Jarjour NN, Dick EC, Busse WW. Detection of rhinovirus RNA in lower airway cells during experimentally induced infection. Am J Respir Crit Care Med. 1997;155(3):1159-61.

21. Jain S, Self WH, Wunderink RG, Fakhran S, Balk R, Bramley $\mathrm{AM}$, et al. Community-acquired pneumonia requiring hospi- talization among U.S. adults. N Engl J Med. 2015;373(5): 415-27.

22. Landry M. Rhinoviruses. In: Versalovic J, Carroll KC, Funke G, Jorgensen JH, Landry ML, Warnock DW, editors. Manual of clinical microbiology. 10th ed. Washington, DC: ASM Press; 2011. p. 1400-9.

23. Ghosh S, Champlin R, Couch R, Englund J, Malik $\mathrm{S}$. Rhinovirus infections in myelosuppressed adult blood and marrow transplant recipients. Clin Infect Dis. 1999;29(3): 528-32.

24. Gutman JA, Peck AJ, Kuypers J, Boeckh M. Rhinovirus as a cause of fatal lower respiratory tract infection in adult stem cell transplantation patients: a report of two cases. Bone Marrow Transplant. 2007;40(8):809-11.

25. Ison MG, Hayden FG, Kaiser L, Corey L, Boeckh M. Rhinovirus infections in hematopoietic stem cell transplant recipients with pneumonia. Clin Infect Dis. 2003;36(9): 1139-43.

26. Jacobs SE, Soave R, Shore TB, Satlin MJ, Schuetz AN, Magro $\mathrm{C}$, et al. Human rhinovirus infections of the lower respiratory tract in hematopoietic stem cell transplant recipients. Transpl Infect Dis. 2013;15(5):474-86.

27. Papadopoulos Nikolaos G, Bates Philip J, Bardin Philip G, Papi A, Leir Shih H, Fraenkel David J, et al. Rhinoviruses infect the lower airways. J Infect Dis. 2000;181(6):1875-84.

28. Jacobs SE, Lamson DM, Soave R, Guzman BH, Shore TB, Ritchie EK, et al. Clinical and molecular epidemiology of human rhinovirus infections in patients with hematologic malignancy. J Clin Virol. 2015;71:51-8.

29. Kraft CS, Jacob JT, Sears MH, Burd EM, Caliendo AM, Lyon GM. Severity of human rhinovirus infection in immunocompromised adults is similar to that of $2009 \mathrm{H} 1 \mathrm{~N} 1$ influenza. J Clin Microbiol. 2012;50(3):1061-3.

30. Seo S, Martin E, Xie H, Kuypers J, Campbell AP, Choi S, Waghmare A, Leisenring W, Jerome K, Englund J, Boeckh. Human Rhinovirus RNA Detection in the Lower Respiratory Tract of Hematopoietic Cell Transplant recipients: Association with Mortality. Abstract presented at: ASBMT Tandem Meeting; 2013;13-17; Salt Lake City, UT.

31. Fuji N, Suzuki A, Lupisan S, Sombrero L, Galang H, Kamigaki $\mathrm{T}$, et al. Detection of human rhinovirus $\mathrm{C}$ viral genome in blood among children with severe respiratory infections in the Philippines. PLoS One. 2011;6(11):e27247.

32. Martin EK, Kuypers J, Chu HY, Lacombe K, Qin X, Strelitz B, et al. Molecular epidemiology of human rhinovirus infections in the pediatric emergency department. J Clin Virol. 2015;62:25-31.

33. Bizzintino J, Lee WM, Laing IA, Vang F, Pappas T, Zhang G, et al. Association between human rhinovirus $\mathrm{C}$ and severity of acute asthma in children. Eur Respir J. 2011;37(5):1037-42.

34. Takeyama A, Hashimoto K, Sato M, Sato T, Kanno S, Takano $\mathrm{K}$, et al. Rhinovirus load and disease severity in children with lower respiratory tract infections. J Med Virol. 2012;84(7): 1135-42.

35. Launes C, Armero G, Anton A, Hernandez L, Gimferrer L, Cisneros $\mathrm{C}$, et al. Molecular epidemiology of severe respiratory disease by human rhinoviruses and enteroviruses at a tertiary paediatric hospital in Barcelona, Spain. Clin Microbiol Infect. 2015;21(8):799.e5-7.

36. Ferguson PE, Gilroy NM, Faux CE, Mackay IM, Sloots TP, Nissen $\mathrm{MD}$, et al. Human rhinovirus $\mathrm{C}$ in adult haematopoietic 
stem cell transplant recipients with respiratory illness. J Clin Virol. 2013;56(3):255-9.

37. Peck AJ, Corey L, Boeckh M. Pretransplantation respiratory syncytial virus infection: impact of a strategy to delay transplantation. Clin Infect Dis. 2004;39(5):673-80.

38. Ljungman P, Gleaves CA, Meyers JD. Respiratory virus infection in immunocompromised patients. Bone Marrow Transplant. 1989;4(1):35-40.

39. Bredius RG, Templeton KE, Scheltinga SA, Claas EC, Kroes AC, Vossen JM. Prospective study of respiratory viral infections in pediatric hemopoietic stem cell transplantation patients. Pediatr Infect Dis J. 2004;23(6):518-22.

40. Templeton KE, Bredius RG, Scheltinga SA, Claas EC, Vossen JM, Kroes AC. Parainfluenza virus 3 infection pre- and posthaematopoietic stem cell transplantation: re-infection or persistence? J Clin Virol. 2004;29(4):320-2.

41. Campbell AP, Guthrie KA, Englund JA, Farney RM, Minerich EL, Kuypers J, et al. Clinical outcomes associated with respiratory virus detection before allogeneic hematopoietic stem cell transplant. Clin Infect Dis. 2015;61(2):192-202.

42. Vu DL, Bridevaux PO, Aubert JD, Soccal PM, Kaiser L. Respiratory viruses in lung transplant recipients: a critical review and pooled analysis of clinical studies. Am J Transplant. 2011;11(5):1071-8.

43. Ambrosioni J, Bridevaux PO, Aubert JD, Soccal P, Wagner G, Kaiser L. Role of rhinovirus load in the upper respiratory tract and severity of symptoms in lung transplant recipients. J Clin Virol. 2015;64:1-5.

44. Johnston SL, Sanderson G, Pattemore PK, Smith S, Bardin $\mathrm{PG}$, Bruce $\mathrm{CB}$, et al. Use of polymerase chain reaction for diagnosis of picornavirus infection in subjects with and without respiratory symptoms. J Clin Microbiol. 1993;31(1): $111-7$.

45. Atmar RL, Georghiou PR. Classification of respiratory tract picornavirus isolates as enteroviruses or rhinoviruses by using reverse transcription-polymerase chain reaction. J Clin Microbiol. 1993;31(9):2544-6.

46. Torgersen H, Skern T, Blaas D. Typing of human rhinoviruses based on sequence variations in the $5^{\prime}$ non-coding region. J Gen Virol. 1989;70(11):3111-6.

47. Lu X, Holloway B, Dare RK, Kuypers J, Yagi S, Williams JV, et al. Real-time reverse transcription-PCR assay for comprehensive detection of human rhinoviruses. J Clin Microbiol. 2007;46(2):533-9.

48. Rollinger JM, Schmidtke M. The human rhinovirus: humanpathological impact, mechanisms of antirhinoviral agents, and strategies for their discovery. Med Res Rev. 2011; 31(1):42-92.

49. Thibaut HJ, Lacroix C, De Palma AM, Franco D, Decramer M, Neyts J. Toward antiviral therapy/prophylaxis for rhinovirus-induced exacerbations of chronic obstructive pulmonary disease: challenges, opportunities, and strategies. Rev Med Virol. 2015. doi:10.1002/rmv.1856 [Epub ahead of print].

50. Hammond C, Kurten M, Kennedy JL. Rhinovirus and asthma: a storied history of incompatibility. Curr Allergy Asthma Rep. 2015;15(2):502.

51. McIntosh K. Coronaviruses. In: Richman D, Whitley RJ, Hayden FG, editors. Clinical virology. New York: Churchill Livingstone; 1997. p. 1123-32.
52. van der Hoek L, Pyrc K, Jebbink MF, Vermeulen-Oost W, Berkhout RJM, Wolthers KC, et al. Identification of a new human coronavirus. Nat Med. 2004;10(4):368-73.

53. Woo PC, Lau SK, Chu CM, Chan KH, Tsoi HW, Huang Y, et al. Characterization and complete genome sequence of a novel coronavirus, coronavirus HKU1, from patients with pneumonia. J Virol. 2004;79(2):884-95.

54. Kuypers J, Martin ET, Heugel J, Wright N, Morrow R, Englund JA. Clinical disease in children associated with newly described coronavirus subtypes. Pediatrics. 2007;119(1): e70-6.

55. Heugel J, Martin ET, Kuypers J, Englund JA. Coronavirusassociated pneumonia in previously healthy children. Pediatr Infect Dis J. 2007;26(8):753-5.

56. Lee J, Storch GA. Characterization of human coronavirus OC43 and human coronavirus NL63 infections among hospitalized children $<5$ years of age. Pediatr Infect Dis J. 2014; 33(8):814-20.

57. Shi Z, Hu Z. A review of studies on animal reservoirs of the SARS coronavirus. Virus Res. 2008;133(1):74-87.

58. Liang WN, Zhao T, Liu ZJ, Guan BY, He X, Liu M, et al. Severe acute respiratory syndrome-retrospect and lessons of 2004 outbreak in China. Biomed Environ Sci. 2006; 19(6):445-51.

59. Rha B, Rudd J, Feikin D, Watson J, Curns AT, Swerdlow DL, et al. Update on the epidemiology of Middle East respiratory syndrome coronavirus (MERS-CoV) infection, and guidance for the public, clinicians, and public health authorities. MMWR Morb Mortal Wkly Rep. 2015;64(3):61-2.

60. Majumder MS, Rivers C, Lofgren E, Fisman D. Estimation of MERS-coronavirus reproductive number and case fatality rate for the Spring 2014 Saudi Arabia outbreak: insights from publicly available data. PLoS Curr. 2014;6.

61. Memish ZA, Al-Tawfiq JA, Assiri A, AlRabiah FA, Al Hajjar $\mathrm{S}$, Albarrak A, et al. Middle east respiratory syndrome coronavirus disease in children. Pediatr Infect Dis J. 2014; 33(9): 904-6.

62. Kumar D, Tellier R, Draker R, Levy G, Humar A. Severe Acute Respiratory Syndrome (SARS) in a liver transplant recipient and guidelines for donor SARS screening. Am J Transplant. 2003;3(8):977-81.

63. Lee N, Hui D, Wu A, Chan P, Cameron P, Joynt GM, et al. A major outbreak of severe acute respiratory syndrome in Hong Kong. N Engl J Med. 2003;348(20):1986-94.

64. Guery B, Poissy J, el Mansouf L, Sejourne C, Ettahar N, Lemaire $\mathrm{X}$, et al. Clinical features and viral diagnosis of two cases of infection with Middle East Respiratory Syndrome coronavirus: a report of nosocomial transmission. Lancet. 2013;381(9885):2265-72.

65. AlGhamdi M, Mushtaq F, Awn N, Shalhoub S. MERS CoV infection in two renal transplant recipients: case report. Am J Transplant. 2015;15(4):1101-4.

66. Oosterhof L, Christensen CB, Sengelov H. Fatal lower respiratory tract disease with human corona virus NL63 in an adult haematopoietic cell transplant recipient. Bone Marrow Transplant. 2010;45(6):1115-6.

67. Pene F, Merlat A, Vabret A, Rozenberg F, Buzyn A, Dreyfus F, et al. Coronavirus 229E-related pneumonia in immunocompromised patients. Clin Infect Dis. 2003;37(7):929-32. 
68. Simon A, Volz S, Fleischhack G, Tillman R, Muller A, Bode $\mathrm{U}$, et al. Human coronavirus OC43 pneumonia in a pediatric cancer patient with Down syndrome and acute lymphoblastic leukemia. J Pediatr Hematol Oncol. 2007;29(6):432-4.

69. Gerna G, Campanini G, Rovida F, Percivalle E, Sarasini A, Marchi A, et al. Genetic variability of human coronavirus OC43-, 229E-, and NL63-like strains and their association with lower respiratory tract infections of hospitalized infants and immunocompromised patients. J Med Virol. 2006;78(7): 938-49.

70. Folz RJ, Elkordy MA. Coronavirus pneumonia following autologous bone marrow transplantation for breast cancer. Chest. 1999;115(3):901-5.

71. Uhlenhaut C, Cohen JI, Pavletic S, Illei G, Gea-Banacloche JC, Abu-Asab M, et al. Use of a novel virus detection assay to identify coronavirus HKU1 in the lungs of a hematopoietic stem cell transplant recipient with fatal pneumonia. Transpl Infect Dis. 2012;14(1):79-85.

72. Gomersall CD, Joynt GM, Lam P, Li T, Yap F, Lam D, et al. Short-term outcome of critically ill patients with severe acute respiratory syndrome. Intensive Care Med. 2004;30(3): 381-7.

73. Monto AS. Coronaviruses. Viral infections of humans. New York: Springer; 1997. p. 211-27.

74. World Health Organization. Laboratory testing for Middle East respiratory syndrome coronavirus 2015. Available from: http://www.who.int/csr/disease/coronavirus_infections/merslaboratory-testing/en/.

75. Stockman LJ, Bellamy R, Garner P. SARS: systematic review of treatment effects. PLoS Med. 2006;3(9):e343.

76. Omrani AS, Saad MM, Baig K, Bahloul A, Abdul-Matin M, Alaidaroos AY, et al. Ribavirin and interferon alfa-2a for severe Middle East respiratory syndrome coronavirus infection: a retrospective cohort study. Lancet Infect Dis. 2014; 14(11):1090-5.

77. Al-Tawfiq JA, Momattin H, Dib J, Memish ZA. Ribavirin and interferon therapy in patients infected with the Middle East respiratory syndrome coronavirus: an observational study. Int J Infect Dis. 2014;20:42-6.

78. Schieble JH, Fox VL, Lennette EH. A probable new human picornavirus associated with respiratory diseases. Am J Epidemiol. 1967;85(2):297-310.

79. Centers for Disease Control and Prevention. Clusters of acute respiratory illness associated with human enterovirus $68-$ Asia, Europe, and United States, 2008-2010. MMWR Morb Mortal Wkly Rep. 2011;60(38):1301-4.

80. Imamura T, Fuji N, Suzuki A, Tamaki R, Saito M, Aniceto R, et al. Enterovirus 68 among children with severe acute respiratory infection, the Philippines. Emerg Infect Dis. 2011;17(8): 1430-5.

81. Imamura T, Suzuki A, Lupisan S, Kamigaki T, Okamoto M, Roy CN, et al. Detection of enterovirus 68 in serum from pediatric patients with pneumonia and their clinical outcomes. Influenza Other Respi Viruses. 2014;8(1):21-4.

82. Kaida A, Kubo H, Sekiguchi J, Kohdera U, Togawa M, Shiomi $\mathrm{M}$, et al. Enterovirus 68 in children with acute respiratory tract infections, Osaka, Japan. Emerg Infect Dis. 2011;17(8):1494-7.
83. Wang YC, Cheng HB, Chen HH, Liu CM, Chou CH, Sung FC. Circulating viruses associated with severe complicated enterovirus infection in Taiwan: a multi-year analysis. Pediatr Infect Dis J. 2010;29(4):334-9.

84. Kreuter JD, Barnes A, McCarthy JE, Schwartzman JD, Oberste MS, Rhodes $\mathrm{CH}$, et al. A fatal central nervous system enterovirus 68 infection. Arch Pathol Lab Med. 2011;135(6): 793-6.

85. Midgley CM, Jackson MA, Selvarangan R, Turabelidze G, Obringer E, Johnson D, et al. Severe respiratory illness associated with enterovirus D68-Missouri and Illinois, 2014. MMWR Morb Mortal Wkly Rep. 2014;63(36):798-9.

86. Bragstad K, Jakobsen K, Rojahn AE, Skram MK, Vainio K, Holberg-Petersen $M$, et al. High frequency of enterovirus D68 in children hospitalised with respiratory illness in Norway, autumn 2014. Influenza Other Respi Viruses. 2015;9(2):59-63.

87. Poelman R, Scholvinck EH, Borger R, Niesters HG, van LeerButer C. The emergence of enterovirus D68 in a Dutch University Medical Center and the necessity for routinely screening for respiratory viruses. J Clin Virol. 2015;62:1-5.

88. Furuse Y, Chaimongkol N, Okamoto M, Imamura T, Saito M, Tamaki R, et al. Molecular epidemiology of enterovirus d68 from 2013 to 2014 in Philippines. J Clin Microbiol. 2015;53(3):1015-8.

89. Drews SJ, Simmonds K, Usman HR, Yee K, Fathima S, Tipples G, et al. Characterization of enterovirus activity, including that of enterovirus D68, in pediatric patients in Alberta, Canada, in 2014. J Clin Microbiol. 2015;53(3): 1042-5.

90. Vongpunsawad S, Prachayangprecha S, Chansaenroj J, Haagmans BL, Smits SL, Poovorawan Y. Genome sequence of enterovirus D68 and clinical disease, Thailand. Emerg Infect Dis. 2015;21(2):384.

91. Pfeiffer HC, Bragstad K, Skram MK, Dahl H, Knudsen PK, Chawla MS, et al. Two cases of acute severe flaccid myelitis associated with enterovirus D68 infection in children, Norway, autumn 2014. Euro Surveill. 2015;20(10):21062.

92. Torres JP, Farfan MJ, Izquierdo G, Piemonte P, Henriquez J, O'Ryan ML. Enterovirus D68 infection, Chile, Spring 2014. Emerg Infect Dis. 2015;21(4):728-9.

93. Reiche J, Bottcher S, Diedrich S, Buchholz U, Buda S, Haas W, et al. Low-level circulation of enterovirus D68-associated acute respiratory infections, Germany, 2014. Emerg Infect Dis. 2015;21(5):837-41.

94. Midgley SE, Christiansen CB, Poulsen MW, Hansen CH, Fischer TK. Emergence of enterovirus D68 in Denmark, June 2014 to February 2015. Euro Surveill. 2015;20(17).

95. Roda D, Perez-Martinez E, Cabrerizo M, Trallero G, MartinezPlanas A, Luaces C, et al. Clinical characteristics and molecular epidemiology of Enterovirus infection in infants $<3$ months in a referral paediatric hospital of Barcelona. Eur J Pediatr. 2015; 174:1549-53.

96. Bal A, Schuffenecker I, Casalegno JS, Josset L, Valette M, Armand N, et al. Enterovirus D68 nosocomial outbreak in elderly people, France, 2014. Clin Microbiol Infect. 2015;21:e61-2. 
97. Parody R, Rabella N, Martino R, Otegui M, del Cuerpo M, Coll $\mathrm{P}$, et al. Upper and lower respiratory tract infections by human enterovirus and rhinovirus in adult patients with hematological malignancies. Am J Hematol. 2007;82(9):807-11.

98. Greninger AL, Naccache SN, Messacar K, Clayton A, Yu G, Somasekar S, et al. A novel outbreak enterovirus D68 strain associated with acute flaccid myelitis cases in the USA (2012-14): a retrospective cohort study. Lancet Infect Dis. 2015;15(6):671-82.

99. Messacar K, Schreiner TL, Maloney JA, Wallace A, Ludke J, Oberste MS, et al. A cluster of acute flaccid paralysis and cranial nerve dysfunction temporally associated with an outbreak of enterovirus D68 in children in Colorado, USA. Lancet. 2015;385(9978):1662-71.

100. Waghmare A, Pergam SA, Jerome KR, Englund JA, Boeckh M, Kuypers J. Clinical disease due to enterovirus D68 in adult hematologic malignancy patients and hematopoietic cell transplant recipients. Blood. 2015;125(11):1724-9.

101. Centers for Disease Control. Enterovirus D68 (EV-D68) 2014 outbreak strain-specific real-time reverse transcription/polymerase chain reaction (rRT-PCR) assay instructions, Atlanta, GA, 2014. p. 1-13.

102. Abzug MJ, Keyserling HL, Lee ML, Levin MJ, Rotbart HA. Neonatal enterovirus infection: virology, serology, and effects of intravenous immune globulin. Clin Infect Dis. 1995;20(5):1201-6.

103. Yen MH, Huang YC, Chen MC, Liu CC, Chiu NC, Lien R, et al. Effect of intravenous immunoglobulin for neonates with severe enteroviral infections with emphasis on the timing of administration. J Clin Virol. 2015;64:92-6.

104. Desmond RA, Accortt NA, Talley L, Villano SA, Soong SJ, Whitley RJ. Enteroviral meningitis: natural history and outcome of pleconaril therapy. Antimicrob Agents Chemother. 2006;50(7):2409-14.

105. Hayden FG, Coats T, Kim K, Hassman HA, Blatter MM, Zhang B, et al. Oral pleconaril treatment of picornavirus-associated viral respiratory illness in adults: efficacy and tolerability in phase II clinical trials. Antivir Ther. 2002;7(1):53-65.

106. Hayden FG, Herrington DT, Coats TL, Kim K, Cooper EC, Villano SA, et al. Efficacy and safety of oral pleconaril for treatment of colds due to picornaviruses in adults: results of 2 double-blind, randomized, placebo-controlled trials. Clin Infect Dis. 2003;36(12):1523-32.

107. Pevear DC, Hayden FG, Demenczuk TM, Barone LR, McKinlay MA, Collett MS. Relationship of pleconaril suscep- tibility and clinical outcomes in treatment of common colds caused by rhinoviruses. Antimicrob Agents Chemother. 2005;49(11):4492-9.

108. Abzug MJ, Michaels MG, Wald E, Jacobs RF, Romero JR, Sanchez PJ, et al. A randomized, double-blind, placebo-controlled trial of pleconaril for the treatment of neonates with enterovirus sepsis. J Pediatric Infect Dis Soc. 2016; $5(1): 53-62$.

109. van der Linden L, Wolthers KC, van Kuppeveld FJ. Replication and inhibitors of enteroviruses and parechoviruses. Viruses. 2015;7(8):4529-62.

110. Allander T, Tammi MT, Eriksson M, Bjerkner A, TiveljungLindell A, Andersson B. From the cover: Cloning of a human parvovirus by molecular screening of respiratory tract samples. Proc Natl Acad Sci U S A. 2005;102(36): 12891-6.

111. Bastien N, Brandt K, Dust K, Ward D, Li Y. Human bocavirus infection, Canada. Emerg Infect Dis. 2006;12(5):848-50.

112. Martin ET, Fairchok MP, Kuypers J, Magaret A, Zerr DM, Wald A, et al. Frequent and prolonged shedding of bocavirus in young children attending daycare. $J$ Infect Dis. 2010;201(11):1625-32.

113. Martin ET, Kuypers J, McRoberts JP, Englund JA, Zerr DM. Human bocavirus 1 primary infection and shedding in infants. J Infect Dis. 2015;212:516-24.

114. Schenk T, Strahm B, Kontny U, Hufnagel M, NeumannHaefelin D, Falcone V. Disseminated bocavirus infection after stem cell transplant. Emerg Infect Dis. 2007;13(9):1425-7.

115. Schenk T, Maier B, Hufnagel M, Strahm B, Kontny U, Neumann-Haefelin D, et al. Persistence of human bocavirus DNA in immunocompromised children. Pediatr Infect Dis J. 2011;30(1):82-4.

116. Waggoner J, Deresinski S. Rare and emerging viral infection in the transplant population. In: Safdar A, editor. Principles and practice of transplant infectious diseases. Berlin: Springer Medizin; 2013.

117. Schildgen O, Muller A, Allander T, Mackay IM, Volz S, Kupfer B, et al. Human bocavirus: passenger or pathogen in acute respiratory tract infections? Clin Microbiol Rev. 2008;21(2):291-304. table of contents.

118. Miyakis S, van Hal SJ, Barratt J, Stark D, Marriott D, Harkness $\mathrm{J}$. Absence of human Bocavirus in bronchoalveolar lavage fluid of lung transplant patients. J Clin Virol. 2009; 44(2):179-80. 